\title{
Financial Technology Application Policy Through Regulation, Collaboration and Financial Literation for Small and Medium Business in Indonesia
}

\author{
Christian Herdinata ${ }^{1, *}$ \\ ${ }^{1}$ Faculty of Management and Business, Universitas Ciputra Surabaya, Indonesia \\ *Corresponding author.Email: christian.herdinata@ciputra.ac.id
}

\begin{abstract}
The Financial Technology (Fintech) market is growing rapidly, alongside the growth of Small and Medium Enterprises (SMEs) in Indonesia. However, there are still no clear legal regulations related to the application of fintech. In addition, collaboration is needed in optimizing the implementation of fintech from related parties. Furthermore, increasing understanding of financial literacy can also be considered as a driving factor in the application of fintech. Therefore, the purpose of this study is to examine policies related to the application of financial technology through regulation, collaboration and financial literacy for small and medium businesses in Indonesia. Clear regulation will increase customer trust, data security and user design appearance, which is what influences the application of fintech. On the other hand, the business and government ecosystems need to maintain collaboration with an active role to encourage the development of fintech collaboration within and throughout the business ecosystem. Furthermore, financial literacy is the best way to teach consumers about the benefits of having a relationship with financial institutions including funding and credit, the ability to build positive finance. This study uses a literature review approach by examining the results of existing studies. The results of this study are expected to be used by the government, business people and society as consumers increase their understanding of the application of fintech and, at the same time, in making strategic policies.
\end{abstract}

Keywords: Collaboration, Financial Literacy, Financial Technology, Regulation.

\section{INTRODUCTION}

Product competitiveness is closely related to the competitiveness of the companies that produce these products. Several indicators used to measure the competitiveness of a product include [1]: (1) share of exports per year (\% of total exports); (2) share of the foreign market per year (\%); (3) export growth rate per year (\%); (4) domestic market share per year (\%); (5) production growth rate per year (\%); (6) the value or price of the product; (7) domestic market diversification; (8) diversification of export markets and (9) customer satisfaction. In order for employers and UMKM workers to play an optimal role, there are at least 5 main prerequisites, namely that they fully have [2]: (1) education; (2) capital; (3) technology; (4) information and (5) other crucial inputs. The problems of Micro, Small and Medium Enterprise (MSMEs) must be resolved immediately so that the continued development of MSMEs can provide support for the country's economy. For that, we need to map how the problems of MSMEs in general are to find the best solutions to make them more developed. In general, MSME problems are related to the following aspects [3]: (1) Market or marketing strengthening; (2) Technology and innovation or technology strengthening; (3) Capital or financial strengthening; (4) Management or management strengthening.

The role of the market is very important for MSMEs where by meeting market criteria, MSMEs can sell goods or services they have for sale and purchase transactions so that MSMEs get sales that are profitable for their business. This aspect is quite important for the growth of MSMEs in Indonesia. Some of them still have problems with this access. In Indonesia, efforts to increase the market are prioritized on reducing barriers to market entry by, among others: (1) Increasing access to market information; (2) Fulfillment of market quality standards; (3) Launching innovative products; (4) Development or 
expansion of target consumers. By mastering this aspect, MSMEs will easily understand the situation and conditions they are experiencing. Furthermore, Sunartiningsih et al. [4] provide recommendations regarding strategies that can be carried out in order to empower MSMEs in Indonesia, namely by managing business networks that are pursued by: (1) subcontracting networks; (2) cluster approach; (3) Franchising and (4) Development of marketing networks. MSMEs in Indonesia generally still carry out the production process manually. This becomes an obstacle when their company is growing. Production activities carried out traditionally will hinder their development process. Thus, it can be said that the problems of technology and innovation must be immediately resolved in MSMEs in Indonesia.

For business actors, the ability to respond quickly to changes and challenges in competition is the key to success. This is closely related to competence in management. Moreover, the issue of globalization has made competition tougher and forced MSMEs to adapt quickly. In general, MSMEs often experience delays in their development. One of the reasons for delays in developing MSMEs is related to business management, namely access to capital [5]. This makes it difficult for MSMEs to compete with large companies. Even some MSMEs tend to have a short-term orientation in decision making in their business. It would be very dangerous if the business decisions were related to financial matters. Many of them have low interest loans from non-bank institutions that are not protected by the government. This is due to their weak knowledge regarding financial literacy. Therefore, strategic efforts are needed to improve the performance and sustainability of MSMEs. One of the ways that can be done is by increasing the knowledge of MSME players on financial knowledge so that management and accountability can be better accounted for like large companies [5]. With good financial knowledge, it is hoped that MSMEs will be able to recognize and access financial resources that will have a positive impact on company growth. Therefore, this study aims to examine the role of regulation, collaboration and financial literacy in the application of financial technology to Micro, Small and Medium Enterprises (MSMEs) in Indonesia.

\section{LITERATURE REVIEW}

Financial management should be of particular concern to business actors, even in the context of a company; financial factors are important to note. This then developed and became known as behavioral finance. Financial behavior is the attitude and behavior of a person in managing their finances, which is marked by the act of consumption, as well as saving [6]. Understanding the concept of financial literacy is very important because it will make it easier for them to know how a value for money will be useful in the present and how much influence it will have in their future. Therefore, MSME strategic efforts are needed to improve their performance and sustainability. MSMEs can improve their performance and sustainability by increasing the knowledge of MSME players on financial knowledge so that management and accountability can be better accounted for as it befits a large company [5]. According to Rohrke and Robinson [7], financial literacy is the best way to teach consumers about the benefits of having a relationship with financial institutions including funding and credit, the ability to build positive finance. The point of view of individuals or families regarding the level of financial literacy influences their ability to have longterm savings. Long-term savings are usually used to own assets (such as land or houses), fulfillment of higher education and retirement funds (pension). With sufficient knowledge of financial literacy, a person is able to make decisions based on relevant information. However, it needs to be realized that financial literacy does not guarantee that the right decisions are made, because a person does not always make decisions based on economic rationale. Widdowson and Hailwood [8] confirms that financial literacy will affect how people save, borrow, invest and manage finances. This financial skill emphasizes the ability to understand the basic concepts of economics and finance to apply them appropriately.

Financial literacy is divided into four aspects, consisting of basic financial knowledge, savings and borrowings, protection (insurance) and investment [9]. (1) Basic financial knowledge includes expenses, income, assets, debt, equity and risks. This basic knowledge is usually related to making decisions in investing or financing, which can affect a person's behavior in managing the money they have; (2) Savings and loans (saving and borrowing). Savings are the accumulation of excess funds obtained by deliberately consuming less than income; (3) Protection (insurance). Insurance is a tool to reduce financial risk, by collecting exposure units in a sufficient number, to make individual losses predictable. Then, this predictable loss is shared equally by those who are members of it; (4) Investment. Investing is saving or placing money so that it can work to make more money.

The important goal of financial literacy is basically to provide financial education to the Indonesian people so that they can manage finances intelligently. Being smart in this case does not require someone to be very proficient in finance, but at least they can plan their financial future. Thus, low knowledge about the financial industry can be overcome [10]. The public is also expected not to be easily fooled into investment products that offer high returns in the short term without considering the risks. This is very dangerous for themselves. It cannot be denied that there are many events that give false expectations regarding investments with high returns. People need to be aware of the dangers 
when investment has a high rate of return. When the risk can be calculated financially, it will at least provide a certain level of security. One solution that a country needs to take is education in the form of public understanding of the products and services offered by financial service institutions. In Indonesia, OJK has implemented this strategy by calling it a national financial literacy strategy program. The National Strategy for Financial Literacy has launched three main pillars, namely [11]: (1) prioritizing educational programs and national campaigns for financial literacy; (2) in the form of strengthening financial literacy infrastructure; (3) talk about developing affordable financial products and services.

The Fintech market is growing rapidly, coupled with the emergence of new start-ups every month, but on the other hand, there is still no clear legal regulation from the government regarding this development of financial technology. Financial technology is developing so fast, it is difficult to manage all its innovative features of legal controls [12]. Empirically, users will consider the factors that influence the expectations of both users and organizations in adopting Fintech, such as customer trust, data security and added value from fintech itself. Everyone has heard about the importance of data security, given that advances in technology have led to an increase in cyber-attacks and hacks. Companies must be prepared to respond to attacks like these instantly, at any time, to avoid litigation, prosecution and reputational damage. Although this is a real threat to the commercial world, this article focuses on technology created by humans to support the financial and legal sectors in service performance. Clear regulations will increase customer confidence, data security and the appearance of user designs that affect the application of Fintech [13].

Today, many countries have specialized institutions to control companies in financial markets. For example, in the UK, there is the Financial Conduct Authority (FCA), an independent non-governmental body. FCA has the obligation and responsibility to regulate companies in the financial sector and implement standards and requirements for financial products, including regulating marketing and financial product behavior to make prohibitions if the application is seen to be inappropriate [12]. Regulatory clarity can serve as the basis for an asset-based non-debt financing system. The financial structure is intended to avoid long-term contractual arrangements between property buyers and property investors other than long-term leases of ownership rights to ownership of money by property buyers. The new class of financial structures has fewer and simpler long-term contract-like terms than the standard examples of shariacompliant finance and conventional debt financing [14]. Many studies argue that the government should answer significant regulatory challenges [15]. Some of the potential risks that may arise in the Fintech business process are fraud risk and data security risk (cybersecurity).

Diverse user needs provide an opportunity for companies to develop several ideas for innovative products simultaneously. Because company resources are limited, companies need to collaborate with other companies to overcome resource limitations to improve new product offerings and reduce the time it takes for users to adopt new products. Collaboration between companies is also needed, because it is a very big task to change consumer choice habits from current products to new products, and no company is large enough to force consumers to adopt new products [16]. Collaboration with other companies in a business ecosystem will result in competence to reach a minimum critical period of adopter and a higher probability, so that innovative financial products will be able to be successfully implemented. Business and government ecosystems need to maintain this active collaboration role to encourage the development of Fintech collaborations within and across the business ecosystem [17]. According to Rong et al. [16], there are three levels of integration resources, namely: (1) integration of communication meeting resources, which refers to building and creating a mutual consensus of identities in the business ecosystem; (2) resource integration in the form of implementation and support meetings that refer to the identification and organization of specific competencies that place different stakeholders into complex resource integration; (3) the implementation and support of the same meetings that formalize synergy among stakeholders. The combination of motives and the integration of resources determine the level of collaboration between companies. Rong et al. [16] further explained the motives for collaboration, namely: (1) reputation. Motive, this refers to how collaboration might enrich a company's reputation; (2) the experimental motive that refers to his way of making structures and hybridization tools from other companies from various industrial lines to be used in their ecosystem. (3) the relationship motive, which refers to strengthening bonds among stakeholders in order to create a mutual sense of urgency towards developing the business ecosystem. Sterman et al. in Teja [17] stated that the strategy of implementing Fintech, which aims to achieve fast growth, can create the risk of overcapacity in the industry. Thus, companies need to overcome these problems by becoming leaders in a business ecosystem through collaboration. By tying up a network of users and changing the role of users to developers, the assumption is that the company will get more acceptance [18]. The transformation of users into developer-users can open up new opportunities [19]; [20]. The prospect of adoption will grow faster than competitors when using collaboration between industry and the business ecosystem. 


\section{METHODS}

This study uses a literature study approach by examining based on previous research then drawing conclusions based on the objectives of the research being carried out. The literature study is carried out by collecting previous research that discusses regulation, collaboration and financial literacy on the application of financial technology. Based on the results of the literature study conducted, the findings are obtained and used as conclusions in this study.

\section{RESULT AND DISCUSSION}

Entrepreneurs are individuals who take on the role of managing the implementation of new resource combinations and capabilities. The entrepreneur's role consists of identifying and implementing new opportunities for the company. Employers or managers must consider digital transformation as a problem value network and not as a value chain in order to find it easier to manage their interactions with actors who are different from their network [21]. Thus, companies need to adopt a business strategy by deploying new digital technologies that can provide complete solutions to meet all the needs of their clients. It is further stated that the company, therefore, needs to maintain the viability of the alliance and create value through networking with the right partners. In this case, the entrepreneur or manager has a big role in implementing innovative business models for the advancement of their business. In the flow of business model innovation, companies need to understand the existence of a combination of management theories such as transaction cost economics, resource-based company views, systems theory and strategic network theory [22]; [23]; [24]. The business model, as both a concept and a construct namely, is how the company creates value, delivers this value to its customers and persuades them to pay, ultimately turning this payment into profit. This business model innovation should begin to be designed through value creation, delivery and capture mechanisms as a strategy that becomes a unit of analysis for technological innovation efforts [25].

An entrepreneurial and innovative organizational culture will connect digital roles and the dynamics of its environment as a force for innovation in its business model. In relation to the digital role, companies should distinguish the dynamics they experience, namely to achieve operational agility and strategic agility. In relation to environmental dynamics, start-up companies will encounter a moderate and even high dynamic situation. Thus, to form an innovative business model, three main things are needed, namely value creation, value capture and value delivery [25] which are implemented with a slice of agile development behavior (agile development) and a lean start up approach. Many studies have looked at how a digital start-up develops their involvement in making innovative business models in the context of various levels of environmental dynamics [25]. We try to frame reality in a model; digital startups in their early stages of development can indeed lead to losses. Companies need to provide a unified framework that links business model innovation, lean start-up approach and agile development and their main steps to achieve operational and strategic agility. Financial markets are becoming increasingly fragmented by globalization and technological change [26]. Big Data (BD) has the potential to 'disrupt' the organization's senior management, encouraging directors to make decisions more quickly and to shape their ability to cope with environmental changes [27]. Big Data can cognitively influence board-level decision-making.

According to [26], Big data is often associated with four elements of the model, namely: (1) Variation- refers to the various types of data collected; (2) Variabilityrepresents the dynamic opportunities available by interpreting unstructured data; (3) Volume- refers to the ability to store and retrieve data efficiently and (4) Veracity- identifies how data is analyzed to ensure all strategies and compliance with regulatory requirements. Data will be quickly collected and processed. Furthermore, Big Compute (BC) is used with the last two conditions of the model, namely: (1) Visualization, which is achieved by using tools such as artificial intelligence to generate models and (2) Value, which includes how a profit-generating strategy can be built and refine differences in micro structure. Some think that big data analysis is a form of "frontier" in data science by creating potential business opportunities, a way to extract opportunities. Managers should give support to their decisions regarding the definition and refinement of a big data analysis strategy, because it is regularly perceived as a significant differentiator between high-performing and low-performing organizations [28]. Many companies are assiduously pursuing the value that big data analysis provides to achieve strategic objectives. However, several journalist studies have found that $43 \%$ of companies see little or no benefit from big data analysis [29]. However, other research on the value of information technology has been widely assessed in the past decade; academics and practitioners are calling for advances in research on the value of big data analysis. The current understanding of how companies should continue to derive value from big data analytics technology is still limited. Big data analysts need not only to have specific skills (such as; problem solving skills, communication and people skills), but also knowledge in statistical analysis, machine learning and business contexts to be able to understand business problems [28].

The importance of time in a more dynamic development of digital financial services operations requires organizational capabilities in physical capacity, human capital and companies. It also emphasizes the impact of limiting constraints on the adoption of digital 
financial services to achieve competitive advantage. Adoption of digital financial services needs to guide organizational design and planning activities, highlighting the needs and value of human capital and company capabilities and the time required for their development in relation to policies and regulations [30]. Identification and skill development are indispensable for managing a business. According to [31], the skills needed are innovation, leadership and management are (1) Innovation skills needed by managers including Capacity to innovate and be creative, Capacity to diversify business areas, Capacity to identify and exploit new business opportunities, Project management skills to relate project objectives to business contexts, Capacity and willingness to take risks, Capacity to organize the resources needed to respond to opportunities, the capacity to create and develop national and international networks. (2) Leadership skills: employee performance, development opportunities, employee motivation, employee satisfaction, communication, managing expectations, integrating cultural differences; (3) Management skills, namely new forms and models of work organization, new technology, organizational change, initiative, decision making and responsibility, capacity to manage strategic agreements and alliances, information analysis, social and relational competence.

\section{CONCLUSION}

What needs to be built in policies related to regulation, collaboration and financial literacy is an understanding of strategic roles that help in understanding the roles of each party correctly and precisely so that they can support specific businesses that move dynamically (firm-specific dynamic capability). On the other hand, there is a need for a strategic planning capability that supports the achievement of adapting to the business model (business model adaptability). In addition, an agile organization is needed to be able to adjust quickly to the changes that occur (organizational agility). Therefore, with all these things, the business will be able to achieve a sustainable optimal value (sustained value).

\section{REFERENCES}

[1] Susilo, Y.S. (2010). Strategi Meningkatkan Daya Saing UMKM Dalam Menghadapi Implementasi CAFTA dan MEA. Buletin Ekonomi Vol. 8, No. 2, Agustus 2010 hal 70-170

[2] Tambunan, T.T.H., 2008, "Ukuran Daya Saing Koperasi dan UMKM", Background Study, RPJM Nasional Tahun 2010-2014 Bidang Pemberdayaan Koperasi dan UKM Bappenas. Diakses dari http://www.kadin-indonesia.or.id pada tanggal 8 September 2010.
[3] Budiarto, Rachmawan, dkk. 2015. Pengembangan UMKM: Antara Konseptual dan Pengalaman Praktis. Yogyakarta : Gadjah Mada University Press.

[4] Sunartiningsih, Agnes dan Hempri Suyatna (2009). Ekonomi Rakyat dalam Pusaran Pasar bebas. Yogyakarta: Media Wacana

[5] Aribawa, D. (2016). Pengaruh Literasi Keuangan Terhadap Kinerja dan Keberlangsungan UMKM di Jawa Tengah. Siasat Bisnis, 20(1), 1-13. https://doi.org/10.20885/jsb.vol20.iss1.art1

[6] Hira, T. K., \& Mugenda, M. (1999). The relationships between self - worth and financial beliefs, behavior, and satisfaction. Journal of Family and Consumer Sciences, 91(4), 76-82

[7] Rohrke, A, \& Robinson, L 2000, 'Guide to Financial Literacy Resources', Journal of Financial Literacy.

[8] Hailwood, DWAK 2007, 'Financial Literacy and its Role in Promoting a Sound Financial System', Reserve Bank of New Zealand, Vol 70, No. 2.

[9] Chen, H \& Volpe, RP. 1998. "An Analysis of Personal Financial Literacy among College Students." Financial Services Review, 7(2), 107 128.

[10] Yushita, A.N. (2017). Pentingnya Literasi Keuangan Bagi Pengelolaan Pribadi. Jurnal Nominal. Vol VI No 1 pp 11-26

[11] Otoritas jasa keuangan. (2013). Strategi Nasional Literasi Keuangan Indonesia. 8 Oktober 2017. www.ojk.go.id.

[12] Kalmykova, Ekaterina., Anna Ryabova. (2016). FinTech Market Development Perspectives. SHS Web of Conferences. Vol 10

[13] Stewart, Harrison,. Jan Jurjens. (2018). Data Security and Consumer trust in Fintech Innovation in Germany.

[14] Graff, Richard A. (2013). A new generation of nondebt fixed-income finance. International Journal of Islamic and Middle Eastern Finance and Management. Vol. 6 No. 4. pp. 267-277

[15]Philippon, Thomas. (2016). The Fintech Opportunity. National Bureu of Economic research. http://www.nber.org/papers/w22476.

[16]Rong, Ke., Yongjiang Shi. (2013). Business ecosystem extension: facilitating the technology substitution. International Journal of Technology Management. Vol 63 no 3.4

[17] Teja, Adrian. (2017). Indonesian Fintech Business: New Innovations or Foster and Collaborate in 
Business Ecosystems?. The Asian Journal of Technology Management. Vol. 10 No. 1 pp 10-18

[18]Lu, C., Rong, K., You, J., \& Shi, Y. (2014). Business ecosystem and stakeholders' role transformation: evidence from chinese emerging electric vehicle industry. Expert Systems with Applications, 41, 4579- 4595.

[19] Overholm, H. (2014). Collectively created opportunities in emerging ecosystems: the case of solar service ventures. Technovation, 39-40, 14-25.

[20] McKelvey, M., Zaring, O., \& Ljungberg, D. (2015). Creating innovative opportunities through research collaboration: an evolutionary framework and empirical illustration in engineering. Technovation, 39-40, 26-36.

[21] Ferreira, J. J., Fernandes, C. I., \& Ferreira, F. A. (2018). To be or not to be digital, that is the question: Firm innovation and performance. Journal of Business Research, 101, 583-590.

[22] Amit, R., \& Zott, C. (2001). Value creation in ebusiness. Strategic Management Journal, 22(6-7), 493-520.

[23] Hedman, J., \& Kalling, T. (2001). The business model: A means to understand the business context of information and communication technology. School of Economics and Management, Lund University.

[24] Morris, M., Schindehutte, M., \& Allen, J. (2005). The entrepreneur's business model: Toward a unified perspective. Journal of Business Research, 58(6), 726-735.

[25] Ghezzi, A., \& Cavallo, A. (2018). Agile business model innovation in digital entrepreneurship: Lean Startup approaches. Journal of business research

[26] Seddon, J. J., \& Currie, W. L. (2016). A model for unpacking big data analytics in high-frequency trading. Journal of Business Research, 70, 300-307.

[27] Merendino, A., Dibb, S., Meadows, M., Quinn, L., Wilson, D., Simkin, L., \& Canhoto, A. (2018). Big data, big decisions: The impact of big data on board level decision-making. Journal of Business Research, 93, 67-78.

[28] Côrte-Real, N., Ruivo, P., Oliveira, T., \& Popovič, A. (2019). Unlocking the drivers of big data analytics value in firms. Journal of Business Research, 97, 160-173.

[29] White, S. (2015). Study reveals that most companies are failing at big data.CIO.com. Retrieved fromhttp://www.cio.com/article/3003538/big- data/study-reveals-thatmost- companies-are-failingat-big-data.html.

[30] David-West, O., Iheanachor, N., \& Kelikume, I. (2018). A resource-based view of digital financial services (DFS): An exploratory study of Nigerian providers. Journal of Business Research, 88, 513526.

[31] Sousa, M. J., \& Rocha, Á. (2019). Skills for disruptive digital business. Journal of Business Research, 94, 257-263. 